\title{
Faktor-Faktor yang Mempengaruhi Penyelesaian Tugas Akhir Mahasiswa Program Studi Akuntansi Universitas Kristen Satya Wacana
}

\author{
Henni Beatrix Modouw ${ }^{1 *}$, Paskah Ika Nugroho ${ }^{2}$ iD \\ ${ }^{12}$ Universitas Kristen Satya Wacana, Salatiga, Indonesia \\ *232016208@student.uksw.edu ${ }^{1 *}$
}

\begin{abstract}
Tujuan penilitian ini adalah untuk menginvestigasi pengaruh motivasi lulus tepat waktu, ketersediaan sumber belajar, kualitas bimbingan tugas akhir dan lingkungan teman sebaya terhadap penyelesaian tugas akhir. Penelitian ini merupakan ex-post facto dengan pendekatan kuantitatif. Responden dalam penelitian ini adalah mahasiswa akuntansi Universitas Kristen Satya Wacana, Salatiga yang sedang mangambil mata kuliah Tugas Akhir sejumlah 60 mahasiswa. Pengumpulan data menggunakan kuesioner melalui google form dan metode analisis data menggunakan regresi berganda. Hasil penelitian menunjukkan bahwa motivasi lulus tepat waktu, ketersediaan sumber belajar, kualitas bimbingan tugas akhir dan lingkungan teman sebaya tidak berpengaruh positif terhadap penyelesaian tugas akhir.
\end{abstract}

Kata kunci: Motivasi Lulus Tepat Waktu, Ketersediaan Sumber Belajar, Kualitas Bimbingan Tugas Akhir, dan Lingkungan Teman Sebaya

\section{Abstract}

The purpose of this study was to investigate the Impact of the motivation of on-time graduation, availability of learning resources, the quality of research consultation, and peer environment to the completion of students' research. This study was an ex-post facto research with the quantitative approach. The respondents of this study are sixty students of the Accounting Program in the Faculty of Economy of Universitas Kristen Satya Wacana who were taking the research course in the second semester of 2020/2021 period. To collect the data, questionnaires were spread in the form of google form and to analyze the data, this study used multiple regression. The result of the study showed that the motivation of on-time graduation, availability of learning resources, the quality of research consultation, and peer environment did not give positive impacts towards the completion of students' research.

Keywords: the Impact of the Motivation of On-time Graduation, Availability of Learning Resources, the Quality of Research Consultation, and Peer Environment to the Completion of Students' Research

\section{Pendahuluan}

Pendidikan menjadi cerminan kualitas suatu negara karena mampu memberikan gambaran kualitas sumber daya manusia di dalamnya. Pendidikan itu sendiri bertujuan untuk mencerdaskan kehidupan bangsa, berbudi perketi luhur, dan keterampilan sebagaimana tertera dalam undang-undang Republik Indonesia Nomor 20 Tahun 2003 Pasal 3 yang berbunyi "Pendidikan nasional berfungsi mengembangkan kemampuan dan membentuk watak serta peradaban bangsa yang bermartabat dalam rangka mencerdaskan kehidupan bangsa, bertujuan untuk berkembangnya potensi peserta didik agar menjadi manusia yang

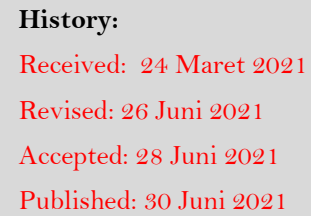

Publisher: Undiksha Press

Licensed: This work is licensed under a Creative Commons Attribution 3.0 License 
beriman dan bertakwa kepada Tuhan Yang Maha Esa, berakhlak mulia, sehat, berilmu, cakap, kreatif, mandiri, dan menjadi warga negara yang demokratis secara bertanggung jawab”.

Berorientasi pada tujuan pendidikan nasional maka dituntut untuk setiap lembaga pendidikan perguruan tinggi dapat menjaga kualitas proses pembelajaran serta meningkatkan kulitas mahasiswa dengan lulusan yang dibekali pengetahuan, keterampilan dan sikap yang baik. Mahasiswa sebagai kaum intelektual berkewajiban untuk meningkatkan mutu diri dengan mempelajari suatu bidang ilmu pengetahuan selama menempuh pedidikan di perguruan tinggi.

Universitas Kristen Satya Wacana merupakan salah satu contoh lembaga perguruan tinggi yang mewujudkan tujuan pendidikan nasional. Sistem pendidikan di UKSW masih menerapkan syarat yang harus ditempuh untuk memperoleh gelar kesarjanaan dengan membuat tugas akhir yang berbobot 9 SKS, dengan melakukan penelitian yang dituangkan dalam bentuk tugas akhir. Dalam buku pedoman tugas akhir (2013) dijelaskan tugas akhir adalah karya tulis ilmiah mahasiswa yang merupakan proses berpikir ilmiah, untuk memenuhi persyaratan memperoleh gelar kesarjanaan.

Dalam proses pembelajarannya, dosen tentunya mengharapkan agar mahasiswa dapat mencapai hasil belajar yang maksimal. Namun tidak sedikit ditemukan mahasiswa UKSW yang kesulitan belajar seperti dalam penyelesaian tugas akhir sehingga target lulus belum tercapai optimal. (Syukri et al., 2019) menyebutkan bahwa faktor-faktor yang dapat menyebabkan kesulitan belajar dikelompokkan menjadi faktor internal dan faktor eksternal. (1) Faktor internal yang dapat menyebabkan kesulitan belajar bagi siswa antara lain; kemampuan intelektual, kepercayaan diri, motivasi, kematangan untuk belajar, usia, jenis kelamin, kebiasaan belajar, serta kemampuan mengindra seperti melihat, mendengar, dan merasakan. (2) Faktor Ekternal yang dapat menyebabkan kesulitan belajar bagi siswa berupa kualitas belajar, fasilitas belajar, serta lingkungan sosial dan alam.

Berdasarkan penelitian yang telah dilakukan oleh (Hartato \& Aisyah, 2016) yang berjudul Faktor-Faktor Yang Mempengaruhi Penyelesaian Tugas Akhir Skripsi (TAS) Mahasiswa Program Studi Pendidikan Akuntansi Fakultas Ekonomi Universitas Negeri Yogyakarta Angkatan 2011, secara parsial menyatakan bahwa faktor yang mempengaruhi penyelesaian tugas akhir yaitu motivasi mahasiswa untuk lulus tepat waktu.

Berdasarkan studi pendahuluan yang telah dilakukan sebelumnya, masih ditemukan banyak mahasiswa tingkat akhir akuntansi UKSW yang belum lulus tepat waktu sehingga menyebabkan beberapa dari mereka terkena readmisi, diduga faktor yang mempengaruhi penyelesaian tugas akhir yaitu mahasiswa masih mengulang mata kuliah, kurangnya motivasi, rasa malas, lingkungan yang tidak mendukung baik lingkungan fisik kondisi kos/rumah, lingkungan sosial seperti; orang tua,teman sebaya, tidak sesuainya judul TA dengan minat mahasiswa, tidak cocok dengan dosen pembimbing, sulitnya menemui dosen pembimbing, sulitnya menemukan sumber belajar yang sesuai dengan teori yang dibutuhkan dan kesibukan mahasiswa itu sendiri seperti merawat keluarga yang sakit, kerja dan organisasi. Namun, ditemukan adanya penelitian yang menyatakan dukungan sosial orang tua dan teman sebaya membantu dalam penyelesaian tugas akhir, yaitu penelitian yang dilakukan oleh (P. Sari \& Indrawati, 2016) yang berjudul Hubungan Antara Dukungan Sosial Teman Sebaya Pada Mahasiswa Tingkat Akhir dan penelitian yang dilakukan oleh (Nurhindazah \& Kustanti, 2016) yang berjudul Hubungan Antara Sosial Orang Tua Pada Mahasiswa Yang Menjalani Tugas Akhir.

Berdasarkan gap research pada penelitian sebelumnya dan uaraian diatas, maka penulis ingin melakukan penelitian ini dengan diberi judul : FAKTOR-FAKTOR YANG MEMPENGARUHI PENYELESAIAN TUGAS AKHIR MAHASISWA PROGRAM STUDI AKUNTANSI UNIVERSITAS KRISTEN SATYA WACANA. 
Penelitian ini dilakukan pada Mahasiswa Prodi Akuntansi UKSW, karena peneliti ingin melihat faktor-faktor apa saja yang mempengaruhi dalam penyelesaian tugas akhir mahasiswa akuntansi UKSW. Peneliti memilih melakukan penelitian di Universitas Kristen Satya Wacana (UKSW) karena Fakultas Ekonomika dan Bisnis Prodi Akuntansi S1 telah berakreditasi A.

Berdasarkan pendahuluan diatas maka tujuan yang ingin dicapai dari penelitian ini adalah untuk : (1) Mengetahui pengaruh motivasi Mahasiswa penyelesaian Tugas Akhir Prodi Akuntansi Universitas Kristen Satya Wacana, (2) Mengetahui pengaruh ketersediaan sumber belajar terhadap penyelesaian Tugas Akhir Mahasiswa Prodi Akuntansi Universitas Kristen Satya Wacana, (3) Mengetahui pengaruh kualitas bimbingan terhadap penyelesaian Tugas Akhir Mahasiswa Prodi Akuntansi Universitas Kristen Satya Wacana, (4) Mengetahui pengaruh lingkungan teman sebaya baik secara personal maupun bersama-sama terhadap penyelesaian Tugas Akhir Mahasiswa Prodi Akuntansi Universitas Kristen Satya Wacana.

Penelitian ini diharapkan dapat memberikan masukan, informasi dan referensi kepada Prodi Akuntansi tentang faktor-faktor yang mempengaruhi proses penyelesaian Tugas Akhir sehingga dapat diupayakan sistem pendidikan khususnya mata kuliah tugas akhir yang lebih baik dan strategi pembelajaran serta pelayanan pendidikan yang lebih optimal bagi mahasiswa. Penelitian ini juga dapat memberikan pengaruh kepada mahasiswa Prodi Akuntansi untuk meningkatkan hal-hal yang mampu mendorongnya dalam proses penyelesaian tugas akhir agar bisa lulus tepat waktu dan menjauhi, meminimalisir hal-hal yang menghambat dalam Penyelesaian Tugas Akhir.

\section{Dasar Teori}

\section{Penyelesaian Tugas Akhir (TA)}

Tugas Akhir merupakan karya tulis ilmiah yang diambil dari hasil penelitian dan analisa permasalahan yang telah dilakukan oleh mahasiswa untuk memenuhi persyaratan kesarjanaan. Menurut (Indarti, 2012) Tugas Akhir adalah suatu karya tulis ilmiah yang berisi tentang fakta dan ulasan yang mendalam dari suatu topik untuk memenuhi syarat penyelesaian program sarjana (S1). Tugas Akhir menjadi mata kuliah wajib bagi setiap Mahasiswa UKSW yang sedang menempuh pendidikan untuk mendapatkan gelar sarjana. Dalam buku Pedoman Penulisan Tugas Akhir Jurusan Pendidikan Akuntansi (UNY, 2011) disebutkan bahwa Tugas Akhir merupakan salah satu persyaratan untuk memperoleh gelar sarjana, jika telah memenuhi kriteria penelitian ilmiah yang berkualitas tinggi, dapat di kembangkan dan memberikan nilai manfaat ekonomi di masa depan.

Menurut Kamus Besar Bahasa Indonesia arti kata penyelesaian adalah suatu proses, perbuatan atau kegiatan yang dilakukan untuk menyelesaiakan suatu pekerjaan. Ini berarti bahwa penyelesaian Tugas Akhir (TA) adalah suatu proses yang harus di selesaiakan oleh mahasiswa selama menjalani pendidikan di perguruan tinggi untuk dapat memperoleh gelar sarjana (S1). Tuntutan dalam penyelesaian Tugas Akhir bagi mahasiswa yaitu harus melakukan proses penelitian dengan benar sesuai dengan kaidah yang telah di tetapkan oleh Universitas tanpa memperbaiki penelitian yang telah ada (Neuzil, 2006). Dengan demikian, jika mahasiswa telah melakukan penelitian sesuai dengan urutan dan langkah-langkah yang benar maka penyelesaian Tugas Akhir (TA) sudah memenuhi syarat untuk memperoleh gelar kesarjanaan.

\section{Motivasi Lulus Tepat Waktu}

Motivasi dalam menjalani pendidikan S1 saat penting guna memberikan semangat kepada mahasiswa untuk cepat menyelesaikan program studi yang sedang dijalani agar mendapatkan gelar sarjana. (Dewi, Istiana Findi Setiawanta, 2014) berpendapat bahwa motivasi adalah kekuatan yang berguna untuk mendorong seseorang dalam menyelesaikan sesuatu tujuan yang telah ditetapkan. Ahli lain juga berpendapat motivasi merupakan keadaan 
dalam pribadi seseorang yang mendorong orang tersebut untuk mencapai suatu tujuan (Saputro \& Pardiman, 2012). Dengan dorongan dan kekuatan yang kuat baik dari luar maupun dari dalam individu itu sendiri maka tujuan yang telah ditetapkan dapat tercapai dengan baik.

Menurut Kamus Besar Bahasa Indonesia arti dari kata lulus adalah keberhasilan yang dicapai oleh seseorang setelah menghadapi cobaan atau ujian. Lulus tepat waktu dalam hal ini adalah kuliah, yang dapat diartikan sebagai keberhasilan seorang mahasiswa dalam menyelesaikan program studi dalam jangka waktu 8 semester seperti yang telah di tetapkan oleh perguruan tinggi di Indonesia.

Berdasarkan penjelasan diatas dapat disimpulkan bahwa motivasi lulus tepat waktu adalah dorongan semangat untuk Mahasiswa dalam menyelesaikan program studi yang sedang di jalani saat ini. Dalam hal ini yang dimaksud adalah mahasiswa penyelesaian Tugas Akhir (TA).

\section{Ketersediaan Sumber Belajar}

Dalam Kamus Besar Bahasa Indonesia ketersediaan berarti kesiapan suatu sarana atau fasilitas baik itu tenaga, barang, modal dan anggaran guna menunjang suatu aktivitas dalam waktu yang telah ditentukan. (Tusriyanto, 2014) mengatakan sumber belajar adalah segala sesuatu yang dapat membantu dan memundahkan dalam proses belajar sehingga dapat memperoleh informasi, pengetahuan dan wawasan yang luas.

Dari penjelasan di atas maka dapat disimpulkan bahwa Ketersediaan Sumber Belajar adalah suatu keadaan dimana bahan Penyelesaian Tugas Akhir tersedia dan dapat digunakan oleh mahasiswa untuk membantu menunjang dalam penyelesaian Tugas Akhir. Sumber belajar merupakan hal yang sangat penting bagi mahasiswa penyelesaian Tugas Akhir karena akan menjadi acuan, pedoman dalam penyelesaian Tugas Akhir (TA).

\section{Kualitas Bimbingan Tugas Akhir}

Menurut Kamus Bahasa Indonesia kualitas adalah tingkat baik buruknya suatu mutu. Sesuatu dikatakan berkualitas jika mempunyai mutu yang baik. (Anwar et al., 2016) mengatakan bahwa bimbingan adalah suatu bantuan yang dilakukan secara terus menerus kepada individu guna memecahkan masalah yang sedang dihadapi dan dapat mengarahkan individu tersebut agar dapat melihat kemampuan dirinya dan merelasasi diri dengan lingkungan di sekitarnya. Dalam hal ini bimbingan dapat diartikan sebagai suatu peroses pemebrian bantuan dari Dosen pembimbing kepada Mahasiswa agar terhindar dari kesulitan dalam penyelesaian Tugas Akhir.

Ini berarti bahwa Kualitas Bimbingan Tugas Akhir adalah tingkatan kadar baik buruknya peroses pemberian bantuan dari Dosen pembimbing kepada mahasiswa agar menghindari kesulitan dalam penyelesaian Tugas Akhir (TA). Peningkatan kualitas bimbingan sangat penting bagi mahasiswa karena bimbingan yang baik dapat mendorong mahasiswa untuk cepat selesai dalam penyelesaian Tugas Akhir (TA).

\section{Lingkungan Teman Sebaya}

Lingkungan adalah gambaran yang meliputi semua kondisi dalam dunia dengan caracara tertentu yang secara tidak langsung dapat mempengaruhi perilaku, pertumbuhan, dan pengembangan kita (Aini \& Taman, 2012). Dalam Kamus Bahasa Indonesia kata Teman diartikan sebagai kawan, sahabat, atau orang yang sama-sama berkerja. Teman Sebaya adalah sederet anak-anak dengan tingkatan usia yang sama (I. K. Sari \& Siswati, 2016).

Lingkungan Teman Sebaya merupakan orang-orang yang memiliki kesamaan usia dan status. Ini berarti dapat di simpulkan bahwa lingkungan teman sebaya adalah kondisi dimana 
terjadi interaksi dengan orang-orang yang mempunyai kesamaan baik itu usia maupun status, yang dapat memberikan pengaruh baik positif maupun negatif (Saputro \& Pardiman, 2012).

\section{Metode}

Populasi dalam penelitian ini adalah mahasiswa Program Studi Akuntansi Universitas Kristen Satya Wacana yang masih aktif dalam perkuliahan. Sampel dalam penelitian ini adalah mahasiswa tingkat akhir yang sedang mengambil penyelesaian Tugas Akhir (TA).

Jenis data yang dipakai dalam penelitian adalah data kuantitatif, yang mana data tersebut berisi tentang informasi jumlah suatu sampel yang akan digunakan. Data dan informasi yang diperlukan dalam penelitian ini bersumber dari data primer. Data primer adalah pengambilan data secara langsung oleh peneliti dari responden melalui angket penelitian dan google form yang diberikan. Dalam hal ini data primer yaitu data yang diperoleh dari hasil penyebaran kuesioner yang di berikan kepada Mahasiswa penyelesaian Tugas Akhir Prodi Akuntansi Universitas Kristen Satya Wacana.

Data dikumpulkan melalui survei dengan menyebarkan kuesioner kepada responden yang akan dilakukan secara langsung kepada yang bersangkutan. Penyebaran kuesioner dilakukan dengan cara mengirimkan email kepada mahasiswa penyelesaian tugas akhir. Metode ini dilakukan untuk mendapatkan data yang berhubungan langsung dengan tujuan dari penelitian ini yaitu tentang Faktor-Faktor Yang Mempengaruhi Penyelesaian Tugas Akhir Mahasiswa Program Studi Akuntansi Universitas Kristen Satya Wacana.

Sampel yang diambil menggunakan metode probability sampling dengan cara memberikan kesempatan yang sama untuk diambil kepada setiap elemen populasi. Pengambilan sampel pada metode ini menggunakan simple random sampling yang dilakukan dengan pengambilan sampel dari anggota populasi secara ajak tanpa memperhatikan tingkatan dalam anggota populasi tersebut. Berdasarkan metode tersebut maka ukuran sampel diambil dari mahasiswa akuntansi UKSW yang sedang mangambil mata kuliah Tugas Akhir.

Penelitian ini menggunakan 2 jenis variabel, yang mana faktor-faktor : motivasi lulus tepat waktu, ketersediaan sumber belajar, kualitas bimbingan tugas akhir dan lingkungan teman sebaya belajar sebagai variabel independen, kemudian variabel dependen yaitu penyelesaian Tugas Akhir.

Dalam menguji suatu variabel, perlu diketahui tentang definisi dari masing-masing variabel, setelah itu melihat indikator dari setiap varibel yang akan diuji dan masuk dalam kategori pada skla jenis apa. Dalam penelitian ini variabel independen yang digunakan ada empat yaitu motivasi lulus tepat waktu (X1), ketersediaan sumber belajar (X2), kualitas bimbingan tugas akhir (X3) dan lingkungan teman sebaya (X4), sedangkan variabel dependen yaitu penyelesaian tugas akhir (Y).

Penelitian ini dilakukan dengan menggunakan metode Statistical product and service solutions (SPSS).

Dalam penelitian ini uji hipotesis dilakukan dengan menggunakan model struktual dengan memakai nilai t-statistik konstruksi dependen, nilai beta untuk hipotesis two tailed (Wijanto \& Sutanto, 2013).

\section{Hasil dan Pembahasan}

Hasil penyebaran kuesioner yang dilakukan kepada mahasiswa yang sedang dalam tahap penyelesaian tugas akhir S1 Program Studi Akuntansi Fakultas Ekonomika dan Bisnis Universitas Kristen Satya Wacana. Kuesioner yang didapatkan berjumlah 60 kuesioner dan kemudian dapat diolah untuk analisis dan uji. Tingkat pengembalian kuesioner dapat dilihat pada tabel 1 . 
Tabel 1. Tingkat Pengembalian Kuesioner

\begin{tabular}{lcc}
\hline Kriteria & Jumlah & Presentase \\
\hline Kuesioner yang disebar & 70 & $100 \%$ \\
\hline Jumlah Kuesioner yang tidak kembali & 10 & $14,3 \%$ \\
\hline Jumlah Kuesioner yang tidak lengkap & 0 & $0 \%$ \\
\hline Jumlah Kuesioner yang kembali & 60 & $85,7 \%$ \\
\hline
\end{tabular}

Data deskriptif terdiri dari empat variabel bebas yaitu motivasi lulus tepat waktu (X1), ketersediaan sumber belajar (X2), kualitas bimbingan tugas akhir (X3) dan lingkungan teman sebaya (X4) serta satu variabel terkait yaitu penyelesaian tugas akhir (Y). Deskriptif data yang disajikan adalah Maximum, Minimum, Mean dan Standar Deviasi.

Tabel 2. Statistik Deskriptif

\begin{tabular}{llllll}
\hline & N & Maximum & Minimum & Mean & Standar Deviasi \\
\hline Motivasi Lulus Tepat Waktu & 60 & 20 & 9 & 16.81667 & 2.361353 \\
\hline Ketersediaan sumber belajar & 60 & 24 & 12 & 18.21667 & 2.35848 \\
\hline Kualitas bimbingan tugas akhir & 60 & 12 & 8 & 10.55 & 1.38300827 \\
\hline Lingkungan teman sebaya & 60 & 12 & 6 & 10.2 & 1.459045427 \\
\hline Penyelesaian tugas akhir & 60 & 32 & 8 & 21.5 & 4.615468 \\
\hline Valid N & 60 & & & & \\
\hline
\end{tabular}

Berdasarkan tabel 2 diatas menunjukan bahwa $\mathrm{N}$ atau jumlah data setiap variabel yang valid berjumlah 60, dari 60 responden. Penyelesaian Tugas Akhir (Y), nilai maximum sebesar 32, nilai minimum 8 , nilai mean 21.05, serta nilai standar deviasi sebesar 4.615468 yang artinya nilai mean lebih besar dari nilai standar sehingga penyimpangan data yang terjadi rendah maka penyebaran nilainya merata.

Motivasi lulus tepat waktu (X1) dari 60 responden diketahui bahwa nilai maximum 20, nilai minimum 9, nilai mean 16.81667, serta nilai standar deviasi sebesar 2.361353 artinya nilai mean motivasi lulus tepat waktu lebih besar dari nilai standar sehingga penyimpangan data yang terjadi rendah maka penyebaran nialainya merata.

Ketersediaan sumber belajar (X2) dari 60 responden diketahui bahwa nilai maximum 24, nilai minimum 12, nilai mean 18.21667, serta nilai standar deviasi sebesar 2.35848 artinya nilai mean lebih besar dari standar deviasi sehingga penyimpangan data yang terjadi rendah maka penyebaran nilainya merata.

Kualitas bimbingan tugas akhir (X3) dari 60 responden diketahui bahwa nilai maximum 12 , nilai minimum 8 , nilai mean 10.55 , serta nilai standar deviasi sebesar 1.38300827 artinya nilai mean lebih besar dari standar deviasi sehingga penyimpangan data yang terjadi rendah maka penyebaran nilainya merata.

Lingkungan teman sebaya (X4) dari 60 responden diketahui bahwa nilai maximum 12, nilai minimum 6, nilai mean 10.2, serta nilai standar deviasi sebesar 1.459045427 artinya nilai mean lebih besar dari standar deviasi sehingga penyimpangan data yang terjadi rendah maka penyebaran nilainya merata.

Tabel 3. Distribusi Frekuensi Variabel Motivasi Lulus Tepat Waktu

\begin{tabular}{lcc}
\hline Kategori & Frekuensi & Presentase \\
\hline Rendah & 1 & $2 \%$ \\
\hline Sedang & 7 & $12 \%$ \\
\hline Tinggi & 14 & $23 \%$ \\
\hline Sangat Tinggi & 38 & $63 \%$ \\
\hline
\end{tabular}


Berdasarkan tabel 3 dapat dilihat bahwa 63\% mahasiswa atau sebanyak 38 siswa memiliki Motivasi luusa Sangat tinggi, yang menunjukan bahwa sebagian besar mahasiswa memiliki motivasi lulus tepat waktu sangat tinggi.

Tabel 4. Distribusi Frekuensi Variabel Ketersediaan Sumber Belajar

\begin{tabular}{lcc}
\hline \multicolumn{1}{c}{ Kategori } & Frekuensi & Presentase \\
\hline Rendah & 1 & $2 \%$ \\
\hline Sedang & 10 & $17 \%$ \\
\hline Tinggi & 35 & $58 \%$ \\
\hline Sangat Tinggi & 14 & $23 \%$ \\
\hline
\end{tabular}

Berdasarkan tabel 4 ketersediaan sumber belajar bagi mahasiswa dianggap tinggi dari 58\% mahasiswa dan $23 \%$ menganggap ketersediaan sumber belajar sangat tinggi, hanya $2 \%$ yang menganggap ketersediaan sumber belajar rendah. Hal ini menunjukkan bahwa ketersediaan sumber belajar dianggap sudah tinggi atau sudah memenuhi kebutuhan mahasiswa untuk mengerjakan tugas akhir.

Tabel 5. Distribusi Frekuensi Variabel Kualitas Bimbingan Tugas Akhir

\begin{tabular}{lcc}
\multicolumn{1}{c}{ Kategori } & Frekuensi & Presentase \\
\hline Rendah & 0 & $0 \%$ \\
\hline Sedang & 1 & $2 \%$ \\
\hline Tinggi & 22 & $37 \%$ \\
\hline Sangat Tinggi & 37 & $62 \%$ \\
\hline
\end{tabular}

Berdasarkan tabel 5 dapat dilihat bahawa kualitas bimbingan tugas akhir yang dilakukan mahasiswa sangat tinggi atau sangat baik yaitu sebanyak $62 \%$.

Tabel 7. Distribusi Frekuensi Variabel Lingkungan Teman Sebaya

\begin{tabular}{lcc}
\hline \multicolumn{1}{c}{ Kategori } & Frekuensi & Presentase \\
\hline Rendah & 1 & $2 \%$ \\
\hline Sedang & 3 & $5 \%$ \\
\hline Tinggi & 22 & $37 \%$ \\
\hline Sangat Tinggi & 34 & $57 \%$ \\
\hline
\end{tabular}

Berdasarkan tabel 7 dapat dilihat bahwa pengaruh dari lingkungan teman sebaya sangat tinggi yaitu sebanyak 57\%.

Tabel 8. Distribusi Frekuensi Variabel Penyelesaian Tugas Akhir

\begin{tabular}{lcc}
\hline \multicolumn{1}{c}{ Kategori } & Frekuensi & Presentase \\
\hline Rendah & 11 & $18 \%$ \\
\hline Sedang & 24 & $40 \%$ \\
\hline Tinggi & 14 & $23 \%$ \\
\hline Sangat Tinggi & 7 & $12 \%$ \\
\hline
\end{tabular}

Berdasarkan informasi pada tabel 8 dapat dilihat bahwa pengaruh dari penyelesaian tugas akhir paling banyak pada kategori sedang yaitu sebanyak $40 \%$. 
Tabel 9. Tabel hasil Regresi

\begin{tabular}{lllc}
\hline \multicolumn{1}{c}{ Variabel } & Koefisien & t & Signifikansi \\
\hline Motivasi Lulus Tepat Waktu $\left(\mathrm{X}_{1}\right)$ & -0.249 & -0.812 & 0.420 \\
\hline Ketersediaan Sumber Belajar $\left(\mathrm{X}_{2}\right)$ & 0.059 & 0.204 & 0.839 \\
\hline Kualitas Bimbingan Tugas Akhir $\left(\mathrm{X}_{3}\right)$ & 0.378 & 0.661 & 0.551 \\
\hline Lingkungan Teman Sebaya $\left(\mathbf{X}_{4}\right)$ & -0.027 & -0.009 & -0.057 \\
\hline
\end{tabular}

Berdasarkan hasil uji regresi dengan spss didapatkan hasil seperti pada tabel 9, dengan nilai konstanta 20.447, dan nilai koefisien tiap variabel seperti pada tabel 9 maka didapatkan persamaan 1 berikut,

$\mathrm{Y}=20.447+(-0.249) x_{1}+0.059 x_{2}+0.378 x_{3}+(-0.027) x_{4}$

Pada pengujian hipotesis 1 , nilai sig $0.420>0.05$ maka motivasi lulus tepat waktu tidak berpengaruh signifikan terhadap penyelesaian tugas akhir. Temuan ini diperkuat dari hasil wawancara yang telah dilakukan kepada beberapa mahasiswa penyelesaian tugas akhir, dengan pernyataan bahwa mereka memang mempunyai motivasi yang sangat tinggi untuk lulus tepat waktu tetapi terkendala dengan seringnya mengulang matakuliah dan juga ada beberapa yang mengulang proposal karena ketidakcocokan dengan dosen pembimbing sehingga memperlambat dalam penyelesaian tugas akhir.

Pada pengujian hipotesis 2, nilai sig. $0.893>0.05$ maka ketersediaan sumber belajar tidak berpengaruh signifikan terhadap penyelesaian tugas akhir. Temuan ini di perkuat dari hasil wawacara yang telah dilakukan kepada beberapa mahasiswa penyelesain tugas akhir, mereka menyatakan bahwa ketersediaan sumber belajar itu banyak tetapi mereka yang malas sehingga memperlambat mereka dalam penyelesaian tugas akhir.

Pada pengujian hipotesis 3, nilai sig. $0.511>0.05$ maka kualitas bimbingan tugas akhir tidak berpengaruh signifikan terhadap penyelesaian tugas akhir. Temuan ini diperkuat dari hasil wanwacara yang telah dilakukan kepada beberapa mahasiswa penyelesaian tugas akhir, yang menyatakan bahwa mereka yang terlalu santai dan malas. Contohnya seperti lebih memilih bermain game di bandingan melakukan bimbingan online sedangan kualitas yang di sediakan sudah sangat baik.

Pada pengujian hipotesis 4 , nilai sig. $-0.057>0.05$ maka lingkungan teman sebaya tidak berpengaruh signifikan terhadap penyelesaian tugas akhir. Temuan ini diperkuat dari dari hasil wawancara yang dilakukan kepada beberapa mahasiswa penyelesaian tugas akhir, mereka menyatakan bahwa lingkungan teman sebaya memang sangat mendukung tetapi kembali lagi pada kendala yang di hadapi yaitu kebanyakan mengulang matakuliah yang nilainya tidak memenuhi standar fakultas sehingga memperlambat mereka dalam menyelesaikan tugas akhir.

\section{Simpulan dan Saran}

Berdasarkan data yang diperoleh dari hasil analisis yang telah dilakukan menunjukan bahwa motivasi lulus tepat waktu, ketersediaan sumber belajar, kualitas bimbingan tugas akhir dan lingkungan teman sebaya tidak berpengaruh positif terhadap penyelesaian tugas akhir.

Berdasarkan pada pengalaman langsung peneliti dalam proses penelitian ini, ada beberapa keterbatasan yang dapat diperhatikan oleh peneliti-peneliti yang akan datang diantaranya yaitu; jumlah responden yang hanya 60 orang, tentunya masih kurang untuk menggambarkan keadaan yang sesungguhnya. Dalam proses pengambilan data, informasi yang diberikan responden melalui kuesioner terkadang tidak menunjukan pendapat yang 
sesungguhnya dari responden dikarenakan perbedaan pemikiran, anggapan dan pemahaman, juga faktor lain seperti kejujuran dalam pengisian kuesioner.

Hasil penelitian menunjukan bahwa motivasi lulus tepat waktu, ketersediaan sumber belajar, kualitas bimbingan tugas akhir dan lingkungan teman sebaya tidak berpengaruh positif terhadap penyelesaian tugas akhir. Oleh sebab itu, peneliti selanjutnya diharapkan menambahkan variabel lainnya yang belum ada pada penelitian ini seperti minat mahasiswa, organisasi, keluarga dan lainnya. Karena masih banyak faktor yang dapat mempengaruhi penyelesaian tugas akhir. Jumlah responden dapat diperbanyak, sehingga akan mendekati gambaran hasil kondisi yang sebenarnya.

\section{Daftar Rujukan}

Abdullah, R. (2012). Pembelajaran Berbasis Pemanfaatan Sumber Belajar. Jurnal Ilmiah Didaktika, 12(2), 216-231. https://doi.org/10.22373/jid.v12i2.449

Aini, P. N., \& Taman, A. (2012). Pengaruh Kemandirian Belajar Dan Lingkungan Belajar Siswa Terhadap Prestasi Belajar Akuntansi Siswa Kelas Xi Ips Sma Negeri 1 Sewon Bantul Tahun Ajaran 2010/2011. Jurnal Pendidikan Akuntansi Indonesia, 10(1), 48-65. https://doi.org/10.21831/jpai.v10i1.921

Amir. H. (2016). Korelasi Pengaruh Faktor Efikasi Diri dan Manajemen Diri Terhadap Motivasi Berprestasi Padamahasiswa Pendidikan Kimia Unversitas Bengkulu. Manajer Pendidikan, 10(4), 336-342.

Anggaeni, P., \& Sujatmiko, B. (2013). Sistem Informasi Tugas Akhir Berbasis Web (Studi Kasus D3 Manajemen Informatika Te Ft Unesa). Jurnal Manajemen Informatika, 2(2), $37-45$.

Anggraini Susi Irmalia. (2001). Motivasi Belajar Dan Faktor-Faktor Yang Berpengaruh: Sebuah Kajian Pada Interaksi Pembelajaran Mahasiswa Irmalia Susi Anggraini *. Jurnal Mahasiswa, 1, 100-109.

Anwar, A., Universitas, A., \& Surabaya, S. G. (2016). Memacu Peningkatan Kualitas Pribadi Untuk Meningkatkan Kualitas Institusi (Telaah Manajemen Sumber Daya Manusia di MI Al Illahiyah Rejoagung Ngoro Jombang). MODELING: Jurnal Program Studi PGMI, 3(2).

Dewi, Istiana Findi Setiawanta, Y. (2014). Pengaruh Persepsi Dan Motivasi Mahasiswa Jurusan Akuntansi Yang Sedang Mengambil Skripsi Terhadap Peminatan Karir Dalam Bidang Perpajakan (Studi Empiris Pada Mahasiwa Akuntansi Universitas Dian Nuswantoro).

Fitriani, A., \& Otok, B. widjanarko. (2013). Pengembangan Indikator Dan Penentuan Rumah Tangga Miskin Dipropinsi Jawa Timur Menggunakan Spatial Structural Equation Modeling. Sains Dan Seni Pomits, 2(1), 84.

Hartato, U., \& Aisyah, M. N. (2016). Faktor - Faktor Yang Mempengaruhi Penyelesaian Skripsi Mahasiswa Pendidikan Akuntansi Universitas Negeri Yogyakarta Angkatan 2011. Jurnal Pendidikan Akuntansi Indonesia, 14(1). https://doi.org/10.21831/jpai.v14i1.11368

Indarti, W. (2012). Analisis Karya Ilmiah (Skripsi) Tugas Akhir Mahasiswa Program Studi Administrasi Pendidikan Periode 2008/2009 Dan 2009/2010. Jurnal EDUCHILD, 1(1), 64.

Muzakir, A. (2014). Prosiding Seminar Nasional Aplikasi Sains \& Teknologi (SNAST) 2014 
Yogyakarta, 15 November 2014 ISSN: 1979-911X. Snast, November, 211-216.

Neuzil, P. (2006). Tuntunan Penulisan Tugas Akhir Berdasarkan Prinsip Dasar Penelitian Ilmiah. Nucleic Acids Research, 34(11), e77-e77.

Nurhindazah, D., \& Kustanti, E. R. (2016). Adversity Intelligence Pada Mahasiswa Yang Diponegoro. 5(4), 645-652.

Nursalam, 2016, metode penelitian. (2013). Perilaku Bullying Ditinjau Dari Peran Kelompok Teman Sebaya Dan Iklim Sekolah Pada Siswa Sma Di Kota Gorontalo. Journal of Chemical Information and Modeling, 53(9), 1689-1699.

Prianto, A., \& Putri, T. H. (2017). Pengaruh Ketersediaan Fasilitas Belajar, Dukungan Orang Tua Yang Dirasakan Terhadap motivasi Dan Prestasi Belajar Siswa Sma Pgri Ngimbang Lamongan. Jurnal Pendidikan Ekonomi, Kewirausahaan, Bisnis, Dan Manajemen (JPEKBM), 1(2), 13-38.

Rahayu, Y. (2013). Peranan Motivasi Terhadap Ketakutan Dan Kekuatiran Dalam Meraih Tujuuan (Studi Kasus Mahasiswa Pasca Magister Manajemen UBB). Junal Khasanah Ilmu, 4(2), 71-76.

Saptono Yohanes Joko. (2016). Motivasi dan keberhasilan belajar siswa. Jurnal Pendidikan Agama Kristen, I(1), 189-212.

Saputro, S. T., \& Pardiman, P. (2012). Pengaruh Disiplin Belajar Dan Lingkungan Teman Sebaya Terhadap Prestasi Belajar Mahasiswa Program Studi Pendidikan Akuntansi Angkatan 2009 Fakultas Ekonomi Universitas Negeri Yogyakarta. Jurnal Pendidikan Akuntansi Indonesia, 10(1), 78-97. https://doi.org/10.21831/jpai.v10i1.923

Sari, I. K., \& Siswati, S. (2016). Hubungan Antara Ketertarikan Interpersonal Dengan Perilaku Prososial Pada Remaja Sma Islam Hidayatullah Semarang. Empati: Jurnal Karya Ilmiah S1 Undip, 5(4), 711-716.

Sari, P., \& Indrawati, E. (2016). Hubungan Antara Dukungan Sosial Teman Sebaya Dengan Resiliensi Akademik Pada Mahasiswa Tingkat Akhir Jurusan X Fakultas Teknik Universitas Diponegoro. Empati, 5(2), 177-182.

Suyono, N. P. D., \& Nugraha, S. P. (2012). Perbedaan Kualitas Persahabatan Mahasiswa Ditinjau Dari Media Komunikasi. Psikologika: Jurnal Pemikiran Dan Penelitian Psikologi, 17(1), 39-44. https://doi.org/10.20885/psikologika.vol17.iss1.art4

Syukri, I. I. F., Rizal, S. S., \& Al Hamdani, M. D. (2019). Pengaruh Kegiatan Keagamaan terhadap Kualitas Pendidikan. Jurnal Penelitian Pendidikan Islam, 7(1), 17. https://doi.org/10.36667/jppi.v7i1.358

Tusriyanto. (2014). Serifikasi Guru Sebagai Upaya Menciptakan Mutu Pendidikan. Tarbawiyah, 11(1), 145-162. http://ejournal.metrouniv.ac.id/index.php/tarbawiyah/article/view/365

UNY, F. (2011). Pedoman Penulisan Tugas Akhir Jurusan Pendidikan Akuntansi.

Wijanto, E. A., \& Sutanto, E. M. (2013). Pengaruh leader member exchange terhadap kepuasan kerja , motivasi kerja dan komitmen organisasional karyawan departemen penjualan pada pt. x. Agora, 1(1), 1-10.

Yuhenita, N. (2015). Bimbingan Sosial Sebagai Upaya Peningkatan Kemampuan Berinteraksi Dengan Teman Sebaya. Jurnal Pendidikan Surya Edukasi, 1(1), 121811.

Zulkifli, N. (2012). Persepsi mahasiswa tentang peranan dosen pembimbing dalam 
pembuatan tugas akhir (skripsi) mahasiswa. Educhild, 01(1), 50-58. 